\title{
Kendali Solar Tracker Menggunakan Selenoid Valve Sebagai Pengendali Aliran Fluida
}

\author{
Yoga Triafandy ${ }^{1}$, Ali Basrah Pulungan ${ }^{2}$, Hamdani ${ }^{3}$ \\ 1,2,3 Universitas Negeri Padang \\ Jl. Prof Dr. Hamka Air Tawar, Padang, Indonesia \\ yoga.triafandy3012@gmail.com¹,alibp@ft.unp.ac.id,hamdani@ft.unp.ac.id ${ }^{2}$
}

\begin{abstract}
The scattered energy that is being developed today is solar energy. Solar energy has tremendous potential as a renewable energy source, estimated to be able to supply energy about 27,000 times the amount of energy produced from all other sources. The solar panel is a tool for converting sunlight into electrical energy. The use of solar panels to maximize the absorption of sunlight can be done in various ways, one of which is implementing a tracking system on solar panels that can make the solar panels always perpendicular to the arrival of sunlight. The tracking system that is mostly developed uses an electric motor as an actuator which requires additional energy in its use. To reduce energy consumption on the actuators, you can use fluid flow control to adjust the direction of movement of the tracker. The control used here uses water for the drive from the solar panel which is controlled by a selenoid valve.
\end{abstract}

\section{Keywords - Selenoid Valve, Aliran fluida and trcaking system}

\begin{abstract}
Abstrak- Energi tebarukan yang banyak dikembangkan saat ini adalah energi surya. Energi matahari memiliki potensi luar biasa sebagai sumber energi terbarukan diperkirakan dapat mensuplai energi sekitar 27.000 kali jumlah energi yang dihasilkan dari semua sumber lainya. Panel surya merupakan salah satu alat untuk mengkonversi cahaya matahari menjadi energi listrik. Penggunaan panel surya untuk memaksimalkan penyerapan cahaya matahari dapat dilakukan dengan berbagai cara salah satunya adalah menerapkan sistem tracking pada panel surya yang bisa membuat panel surya itu selalu tegak lurus terhadap datangnya cahaya matahari. Sistem tracking yang banyak dikembangkan menggunakan motor listrik sebagai aktuator yang membutuhkan energi tambahan dalam penggunaannya. Untuk mengurangi komsumsi energi pada aktuator yang digunakan bisa dengan pengendalian aliran fluida untuk mengatur arah pergerakan tracker. Kendali yang digunakan disini menggunakan air untuk penggerak dari panel surya yang dikontrol dengan selenoid valve.
\end{abstract}

Kata kunci-Selenoid Valve,Aliran fluida dan Sistim trcaking

\section{Pendahuluan}

Energi terbarukan yang banyak dikembangkan saat ini adalah energi surya. Energi surya adalah energi yang berupa sinar dan panas dari matahari. Penggunaan cahaya matahari sebagai sumber energi sangat memungkinkan dalam pembangkitan energi listrik terutama pada daerah khatulistiwa khusunya indonesia. Dalam memaksimalkan konversi enrgi listrik yang dihasilkan panel surya, maka bidang panel surya harus menghadap sinar datang matahari.[1]

Pertumbuhan konsumsi energi di indonesia rata-rata 8.1\% pertahun, belum berimbang dengan pertumbuhan pembangkitan energi listrik yang tumbuh rata-rata 5.2\% pertahun.[2] Energi matahari memiliki potensi luar biasa sebagai sumber energi terbarukan diperkirakann dapat mensuplai energi sekitar 27.000 kali jumlah energi yang dihasilkan dari semua sumber lainya.[3]

Sistem panel surya tetap memiliki nilai efisiensi yang rendah yaitu kurang dari $20 \%$ disebabkan karena bahan yang terbatas dan juga posisi matahari yang berubah setiap waktunya. Efisiensi dapat ditingkatkan dengan mengatur orientasi di panel surya dengan menerapkan sistem pelacak surya pasif atau aktif.[4]

Penggunaan sistem panel surya banyak menggunakan motor listrik sebagai aktuatornya, sehingga membutuhkan energi tamabahan untuk menyuplai aktuator tersebut. Kebayakan motor yang digunakan sebagai aktuator yaitu motor DC yang kebutuhan energi untuk aktuator tersebut sebesar $0,624 \mathrm{Wh} /$ hari ini untuk menyuplai aktuator dalam kondisi aktif selama 100 detik.[1] Pada alat ini menggunakan massa fluida sebagai pengendalian orientasi panel surya untuk menghemat konsumsi energi.

\section{Selenoid valve}

Selenoid Valve merupakan katup yang dikendalikan dengan arus listrik melalui kumparan selenoida. Selenoid Valve ini merupakan elemen kontrol yang paling sering digunakan pada sistim fluida contohnya pada sistem pneumatic sistim hidrolik. Selenoid Valve bertugas untuk mengontrol saluran udara yang bertekanan menuju aktuator pneumatic (cylinder) dan juga pada tandon air yang membutuhkan selenoid valve sebagai pengatur pengisian air.[6] 


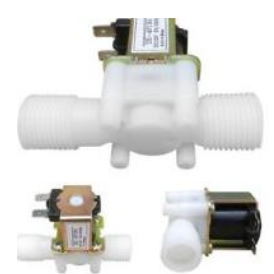

Gambar 1. Selenoid Valve

\section{Arduino Uno}

Arduino Uno adalah Arduino board yang menggunakan mikrokontroler Atmega128. Arduino Uno memiliki 14 pin digital (6 pin dapat digunakan sebagai output PWM), 6 input analog, sebuah $16 \mathrm{MHz}$ osilator kristal, sebuah koneksi USB, sebuah konektor sumber tegangan sebuah header ICSP, dan sebuah tombol reset. Arduino Uno memuat segala hal yang dibutuhkan untuk mendukung sebuah mikrokontroler. [7]

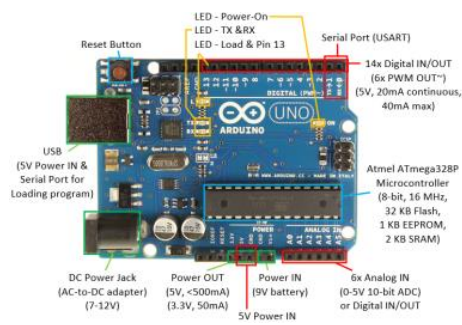

Gambar 2. Arduino Uno

\section{Real Time Clock (RTC)}

Real Time Clock (RTC) adalah perangkat yang memungkinkan untuk menghasilkan waktu yang tepat karena dilengkapi pembangkit waktu dan baterai, modul RTC yang digunkan pada penelitian adalah DS1307 yang merupakan salah satu sensor yang dapat menyimpan variabel waktu, tanggal, dan tahun secara real time. Komunikasi yang digunakan oleh sensor DS1307 adalah komunikasi 12C yang hanya membutuhkan 2 buah port SDA dan SCL untuk membaca isi register dari sensor RTC. [8]

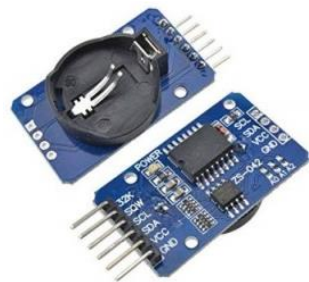

Gambar 3. Real Time Clock (RTC)

\section{Liquid Crystal Display (LCD)}

Liquid crystal display berfungsi menampilkan suatu nilai hasil sensor, menampilkan teks, atau menampilkan menu pada aplikasi mikrokontroler. LCD yang digunakan adalah jenis LCD M1632 yang merupakan modul LCD dengan tampilan $16 \times 2$ baris dengan konsumsi daya rendah. [9]

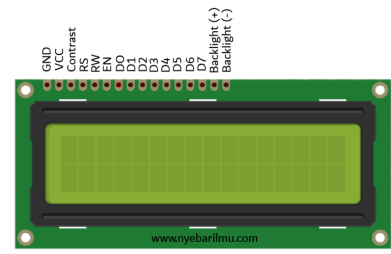

Gambar 4. Liquid Crystal Digital (LCD)

\section{Driver IC ULN 2803A}

Komponen utama pembentuk rangkaian driver berupa IC ULN 2803A yang merupakan transistor dan relay. IC ULN 2803A adalah chip integrated circuit (IC) berupa rangkaian transistor darlinton dengan tegangan tinggi. Hal ini memungkinkan untuk membuat antarmuka sinyal dengan beban tegangan tinggi dan bertindak sebagai relay, yaitu menyalakan atau mematikan tingkat sinyal yang lebih tinggi di sisi yang berlawanan. [11]

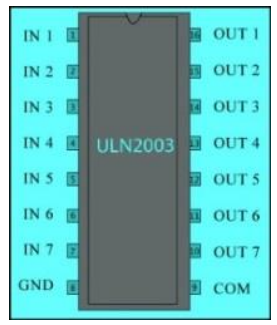

Gambar 5. Driver IC ULN 2803A

\section{Sensor Accelerometer Adxl345}

Accelerometer adalah alat yang digunakan untuk mengatur percepatan, mendeteksi dan mengukur getaran (vibrasi), dan mengukur percepatan akibat gravitasi (inklinasi). Accelerometer Adxl235 memiliki sumbu x, y, dan z. Modul ini juga memiliki daya yang rendah dan resolusi 13bit. Resolusi yang dimiliki mampu mengukur perubahan sudut dibawah 1 derajat. [12]

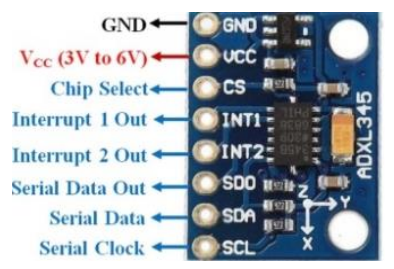

Gambar 6. Sensor Accelerometer Adxl345

\section{Power Supply Swicthing}

Switching power supply atau yang lebih dikenal dengan switched mode power supply (SMPS), adalah catu daya elektronik yang terdiri darisebuah regulasi switching yang disediakan sesuai kebutuhan pada tegangan keluaran.[13]

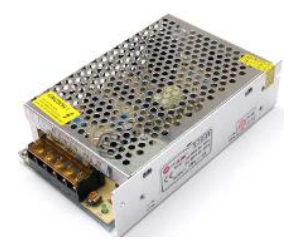

Gambar 7. Power Supply Switching 


\section{METODE}

Pada bab ini akan membahas tentang perancangan hardware dan software yang terdiri dari blok diagram, perancangan mekanik dan flowchart.

\section{Blok Diagram}

Pada tugas akir ini, perancangan kendali orientasi panel surya dengan pengendalian massa fluida menggunakan selenoid valve terdiri dari beberapa bagian yaitu : Rangkaian power supply 5 Vdc, RTC DS1307, driver relay, LCD 16 x 2 dan arduino Atmega328.

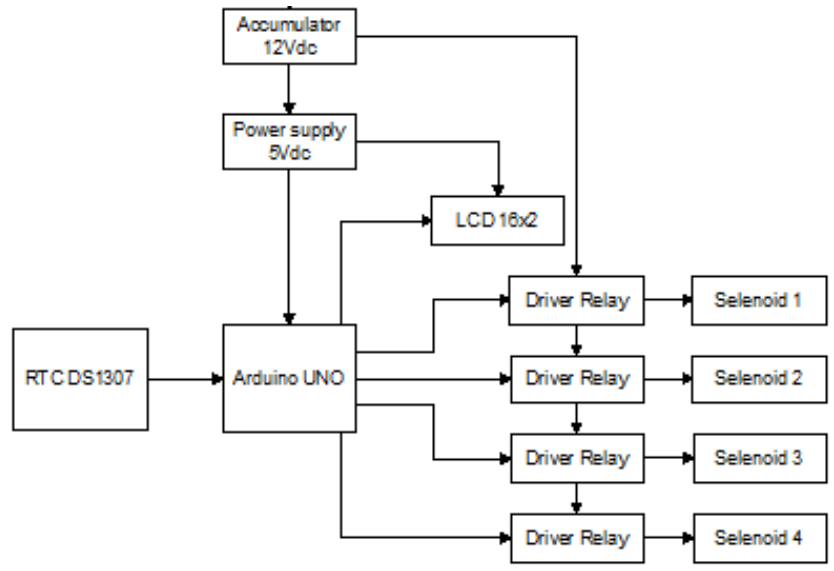

Gambar 8. Blok Diagram Keseluruhan

Berdasarkan blok diagram keseluruhan sistem di atas, fungsi dari masing-masing blok diagram sebagai berikut:

\section{Arduino UNO}

Merupakan bagian yang berfungsi untuk memproses input yang dimasukan dan menghasilkan output berupa aktifasi pada selenoid pada jalur masukan dan jalur keluaran pada pengaturan sudut solar cell terhadap cahaya matahari.

2. RTC DS1307

Difungsikan sebagai data pewaktu dalam pengaturan pendeteksian cahaya matahari terhadap sudut kemiringan dari solar cell.

3. LCD $16 \times 2$

Berfungsi sebagai media tampilan waktu dan sudut kemiringan dari pendeteksian cahaya matahari terhadap sudut kemiringan dari solar cell.

5. Selenoid Valve

Merupakan penggerak dalam memasukan air kedalam wadah dan mengeluarkan air dari wadah penampung.

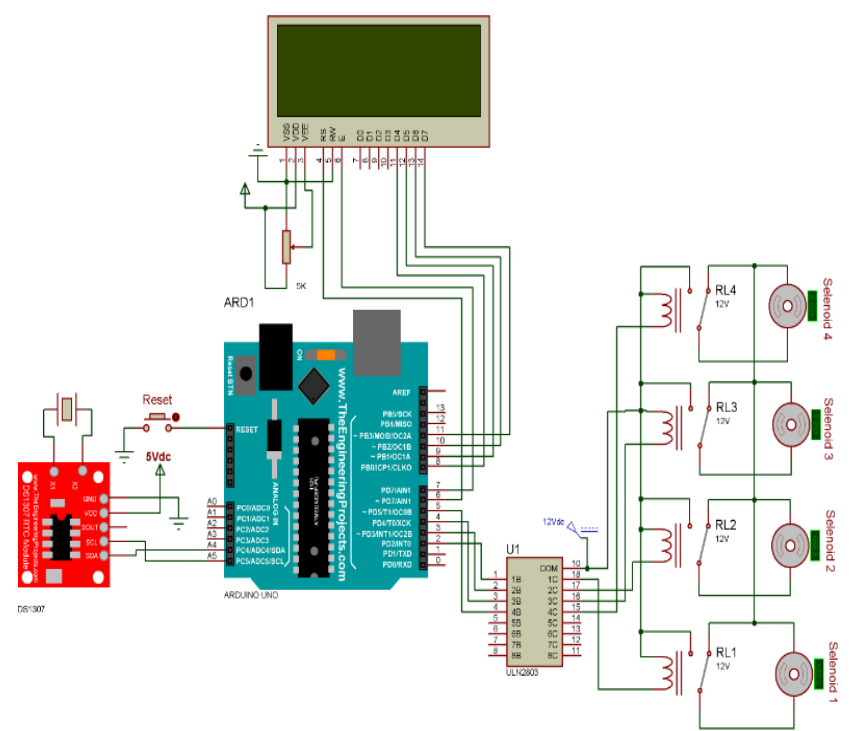

Gambar 9. Rangkaian Elektronika Keseluruhan

\section{Perancangan Mekanik(hardware)}

Perancangan mekanik hardware merupakan hal yang sangat penting dalam pembuatan tugas akhir ini. Karena dengan adanya hardware barulah sistem dapat diuji secara nyata apakah tugas akhir ini dapat bekerja dengan baik atau tidak. Rancangan hardware dari tugas akhir ini dapat dilihat seperti dibawah ini.

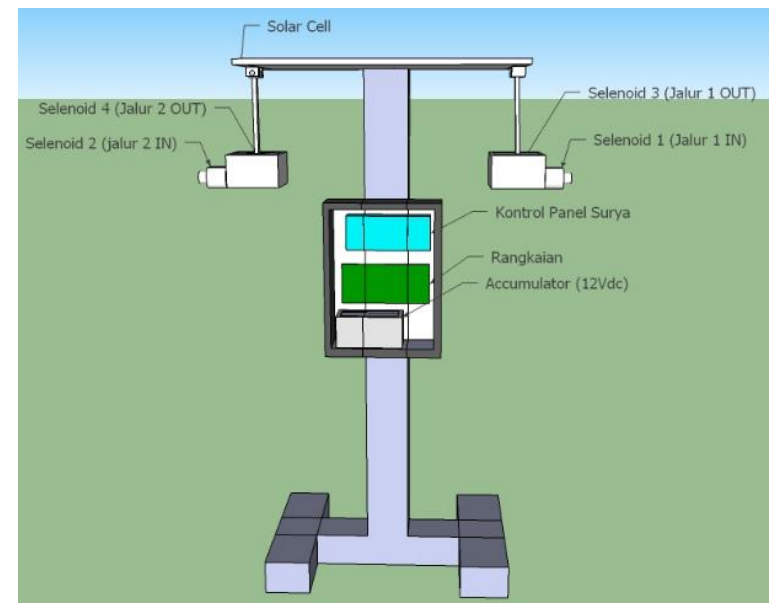

Gambar 10. Rancangan Hardware Tampak Depan

\section{Flowchart}

Flowchart adalah diagram alur pada perancangan program yang akan dibuat yang sesuai dengan prinsip kerja alat. Berikut adalah rancangan Flowchart Alat Kendali Orientasi Panel Surya. 


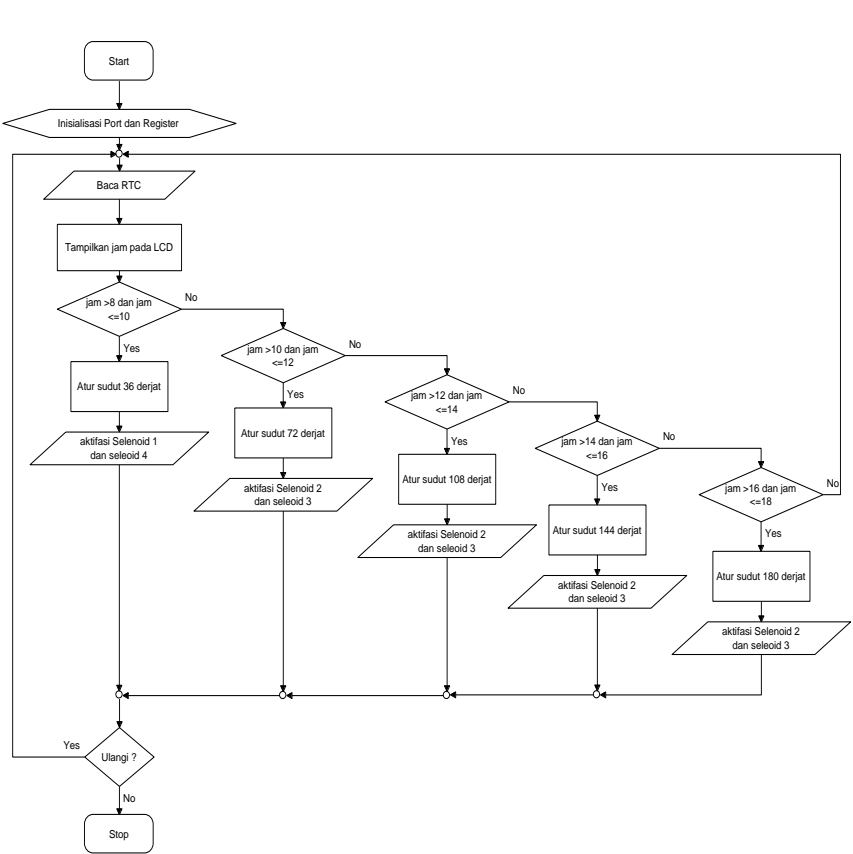

Gambar 11. Flowchart Sistem Arduino

Pada gambar 5 diatas merupakan flowchart atau diagram alur cara kerja alat keseluruhan, sistem diawali dengan mengaktifkan alat dan aktifasi alat akan menghidupkan alat dan selanjutnya sistem akan menampilkan informasi jam, menit, dan detik. Dari penampilan waktu tersebut, maka sistem akan mengkatifkan selenoid 1 (jalur 1 masukan air ke wadah 1) dan selenoid 2 (jalur 2 masukan air ke wadah 2), jika sudut kemiringan telah sesuai dari pengaturan program yang telah dibuat maka sistem akan dalam kondisi standby sampai perubahan waktu dari pembacaan terhadap RTC yang ditampilkan pada LCD, pengaturan sudut kemiringan solar cell terhadap waktu telah dirancang dan ditanamkan didalam program, perubahan sudut kemiringan ini telah diatur pada program yaitu dalam memasukan air dan mengeluarkan air pada wadah 1 dan wadah 2, dan bagian keluaran air pada wadah 1 dan diatur oleh selenoid 3, dan keluaran air pada wadah 2 diatur oleh selenoid 4 .

\section{HASIL DAN PEMBAHASAN}

Pengujian alat dilakukan untuk mengetahui apakah alat yang dibuat bekerja dengan baik atau tidak. Adapun beberapa pengujian yang penulis lakukansebagai berikut.

1. Pengujian Catu Daya

Pengujian dilakukan untuk tegangan masukan power supply dan tegangan keluaran 5VDC dan 12VDC dari catu daya tersebut. Berikut hasilnya

Tabel 1. Hasil Pengujian Catu Daya

\begin{tabular}{|c|c|c|}
\hline No & Parameter Yang Diukur & $\begin{array}{c}\text { Hasil } \\
\text { Pengukuran }\end{array}$ \\
\hline 1 & $\begin{array}{c}\text { Tegangan masukan } \\
\text { Power Pupply }\end{array}$ & 231 VAC \\
\hline 2 & $\begin{array}{c}\text { Tegangan Keluaran } \\
\text { Power supply swicthing }\end{array}$ & 12,34 VDC \\
\hline
\end{tabular}

\begin{tabular}{|c|c|c|}
\hline 3 & $\begin{array}{c}\text { Tegangan keluaran } \\
\text { Power Supply Step Down }\end{array}$ & 5,04 VDC \\
\hline
\end{tabular}

2. Pengujian Rangkaian Selenoid

Pengujian dilakukan dengan mengukur tegangan masukan dari selenoid. Berikut hasil pengukuran yang didapat

Tabel 2. Hasil Pengukuran Rangkaian Selenoid

\begin{tabular}{|c|c|c|c|c|}
\hline $\begin{array}{c}\mathrm{N} \\
\mathrm{o}\end{array}$ & Parameter & $\begin{array}{c}\text { Tegangan } \\
(\mathrm{V})\end{array}$ & $\begin{array}{c}\text { Arus } \\
(\mathrm{A})\end{array}$ & Kondisi \\
\hline 1 & Vin & $12,12 \mathrm{Vdc}$ & 0.25 & ON \\
\hline 2 & Vin & $0 \mathrm{Vdc}$ & 0.1 & OFF \\
\hline
\end{tabular}

3. Pengujian Massa fluida (Air)

Pengujian dilakukan dengan mengukur volume massa fluida (Air) pada wadah kanan dan kiri disetiap perpindahan posisi.

Tabel 3. Hasil Pengukuran Massa fluida (Air)

\begin{tabular}{|c|c|c|c|}
\hline Sudut & Jam & $\begin{array}{c}\text { Volume } \\
\text { Wadah Kanan }\end{array}$ & $\begin{array}{c}\text { Volume } \\
\text { Wadah Kiri }\end{array}$ \\
\hline $\begin{array}{c}\text { Posisi 1 } \\
\left(30^{\circ}\right)\end{array}$ & 07.00 & 0 & $1 \mathrm{~L}$ \\
\hline $\begin{array}{c}\text { Posisi } 2 \\
\left(60^{\circ}\right)\end{array}$ & 09.00 & $370 \mathrm{~mL}$ & $750 \mathrm{~mL}$ \\
\hline $\begin{array}{c}\text { Posisi } 3 \\
\left(90^{\circ}\right)\end{array}$ & 11.00 & $500 \mathrm{~mL}$ & $500 \mathrm{~mL}$ \\
\hline $\begin{array}{c}\text { Posisi } 4 \\
\left(120^{\circ}\right)\end{array}$ & 13.00 & $700 \mathrm{~mL}$ & $350 \mathrm{~mL}$ \\
\hline $\begin{array}{c}\text { Posisi } 5 \\
\left(150^{\circ}\right)\end{array}$ & 15.00 & $1,3 \mathrm{~L}$ & 0 \\
\hline
\end{tabular}

4. Pengujian Kecepatan Angin

Pengujian ini dilakukan dengan mengukur kecepatan angin menggunakan anemometer saat proses pengujian panel surya untuk melihat dari pengaruh angin terhadap posisi kemiringan dari panel surya. Berikut hasil pengukuran yang didapat.

Tabel 4. Hasil Pengukuran Kecepatan Angin

\begin{tabular}{|c|c|c|c|}
\hline No & Jam & $\begin{array}{c}\text { Kecepatan } \\
\text { Angin }(\mathrm{m} / \mathrm{s})\end{array}$ & Posisi \\
\hline 1 & 07.00 & $0.8 \mathrm{~m} / \mathrm{s}$ & 1 sudut $\left(30^{\circ}\right)$ \\
\hline 2 & 09.00 & $2.4 \mathrm{~m} / \mathrm{s}$ & 2 sudut $\left(30^{\circ}\right)$ \\
\hline 3 & 11.00 & $1.7 \mathrm{~m} / \mathrm{s}$ & 3 sudut $\left(90^{0}\right.$ \\
\hline 4 & 13.00 & $4.3 \mathrm{~m} / \mathrm{s}$ & 4 sudut $\left(120^{\circ}\right)$ \\
\hline 5 & 15.00 & $2.3 \mathrm{~m} / \mathrm{s}$ & 5 sudut $\left(150^{\circ}\right)$ \\
\hline
\end{tabular}

Dari hasil pengukuran dari beberapa rangkaian yang telah dilakukan pada catu daya, selenoid valve, massa fluida dan kecepatan angin setelah dibandingkan dengan data sheet komponen hasil yang didapat masih dalam rentangan tegangan kerja dari komponen komponen tersebut, sedangkan konsumsi daya yang diperlukan selenoid valve pada saat keadaan aktif sebesar $0.303 \mathrm{Wh}$ /hari lebih kecil 0,51\% dibandingkan 
dengan konsumsi daya yang menggunakan aktuator motor DC yaitu sebesar 0,624 Wh/hari jadi penggunaan pengendalian aliran fluida untuk sistem tracker ini lebih efisien dalam penghematan energi. Berdasarkan kecepatan angin pada saat pengukuran tidak memeperngaruhi secara siknifikan.

\section{PENUTUP}

Berdasarkan dari pengujian yang dilakukan diatas maka dapat disimpulkan bahwa alat kendali solar tracker menggunakan selenoid valve sebagai pengendali aliran fluida ini sudah bekerja dengan baik dan juga penggunaan aliran fluida dengan pengendalian selenoid valve dapat mengendalikan solar tracker sehingga penggunnaan ini juga dapat menghemat konsumsi daya listrik pada aktuatornya. Namun, sedikit saran untuk peneliti selanjutnya yaitu penambahan pompa air untuk selenoid sehingg air yang masuk dan keluar dari selenoid bisa lebih besar dan tekanannya lebih tinggi.

\section{REFERENSI}

[1] W. Yandi, S. Syafii, and A. B. Pulungan, "Tracker Tiga Posisi Panel Surya untuk Peningkatan Konversi Energi dengan Catu Daya Rendah," J. Nas. Tek. Elektro, vol. 6, no. 3, pp. 159-167, 2017.

[2] P. T. PLN, "Rencana Usaha Penyediaan Tenaga Listrik (RUPTL) 2016-2025," Kementeri. Energi dan Sumber Daya Miner., pp. 380-386, 2016.

[3] C. Alexandru and N. Irina Tatu, "Optimal design of the solar tracker used for a photovoltaic string," $J$. Renew. Sustain. Energy, vol. 5, no. 2, p. 23133, 2013.

[4] A. B. Pulungan, L. Son, and S. Huda, "Semi Active Control of Solar Tracker Using Variable Position of Added Mass Control," in 2019 16th International Conference on Quality in Research (QIR): International Symposium on Electrical and Computer Engineering, 2019, pp. 1-5.

[5] A. B. Pulungan, L. Son, and S. Syafii, "A Review of Solar Tracker Control Strategies," Proceeding Electr. Eng. Comput. Sci. Informatics, vol. 5, no. 1, pp. 319323, 2018.

[6] R. Latuconsina, L. H. Laisina, and A. Permana, "Pemanfaatan Sensor PIR (Passive Infrared Receiver) dan Mikrokontroler Atmega 16 Untuk Efisiensi Pemakaian Air Wudhu," J. Inform. J. Pengemb. IT, vol. 2, no. 2, pp. 18-22, 2017.
Berbasis Arduino Uno," 2015.
[8] M. Y. Mustar and R. O. Wiyagi, "Implementasi Sistem Monitoring Deteksi Hujan dan Suhu Berbasis Sensor Secara Real Time," Semesta Tek, vol. 20, no. 1, pp. 20-28, 2017.

[9] D. Anggraini and Y. Yuniarto, "Aplikasi Mikrokontroler atmega16 sebagai pengontrol sistem emergency dan lampu jalan yang dilengkapi dengan sensor cahaya (ldr) pada miniatur kompleks perumahan modern.” Undip, 2010.

[10] R. Nandika and P. Gunoto, "Pemanfaatan Sel Surya 50 Wp Pada Lampu Penerangan Rumah Tangga di Daerah Hinterland," Sigma Tek., vol. 1, no. 2, pp. 185-195, 2018.

[11] L. Apri, "Rancang Bangun Sistem Saklar Universal Berbasis Raspberry Pi Dengan Teknologi Websocket." Politeknik Negeri Sriwijaya, 2016.

[12] M. Liandana, B. M. S. Nirmala, and T. Bali, "Wearable Device untuk Merekam Data Akselerasi Aktivitas Fisik Menggunakan Sensor Accelerometer," J. Explor. STMIK Mataram-Volume, vol. 9, no. 1, 2019.

[13] I. M. Arifana, "Rancang bangun power supply switching dengan arus dan tegangan terkendali sebagai catu daya proses elektropleting logam." Universitas Islam Negeri Maulana Malik Ibrahim, 2016.

\section{Biodata Penulis}

Yoga Triafandy, lahir di Rao, 30 Desember 1997.Menyelesaikan studi DIV Teknik Elektro Industri pada Jurusan Teknik Elektro Fakultas Teknik Universitas Negeri Padang.[1]

Ali Basrah Pulungan,S.T, M.T, lahir di Hutanaingkan, 12 Desember 1974. Staf pengajar di Jurusan Teknik Elektro Fakultas Teknik Universitas Negeri Padang (FT-UNP) sejak tahun 2003.[2]

Hamdani, S.Pd., M.Pd.T.. Staf pengajar di Jurusan Teknik Elektro Fakultas Teknik Universitas Negeri Padang (FTUNP).[3] 